\title{
Analysts or Vultures: Do Transient Investors Target Firms with Lower Financial Reporting Quality?
}

\author{
Todd Palmer White ${ }^{1}$ \\ ${ }^{1}$ Western Michigan University, USA \\ Correspondence: Todd Palmer White, Western Michigan University, USA. E-mail: todd.white@wmich.edu
}

Received: August 21, 2013

Accepted: October 24, 2013

Online Published: October 28, 2013

doi:10.5430/afr.v2n4p110

URL: http://dx.doi.org/10.5430/afr.v2n4p110

\begin{abstract}
This study examines the portrayal of transient investors as short-termists who exploit poorly monitored firms against the competing portrayal of transient investors as informed investors. More specifically, the study examines 1) whether transient institutional investors directly target firms which exercise greater accounting discretion and 2) whether the superior abnormal returns earned by transient investors are more prevalent in firms with greater accounting discretion. The tests are performed using a linear regression model on a panel dataset. Three proxies, adapted from prior literature, are used to measure accounting discretion, abnormal accruals, earnings smoothing, and the incidence of small positive earnings surprises. Results are inconsistent with the short-termist portrayal of transient investors. Transient investors are not found to invest more heavily in firms with greater accounting discretion. Furthermore, the positive abnormal returns earned by transient investors are not more prevalent in firms with greater accounting discretion. By providing results that contradict the portrayal of transient investors as short-termists who exploit poorly monitored firms, the current study makes an important contribution to the debate regarding the effects of a short-term institutional investor base on firm value.
\end{abstract}

Keywords: Transient investors, Accounting discretion, Firm monitoring, Short-termism

\section{Introduction}

Short-term institutional investors, otherwise known as "transient investors" are portrayed in the accounting and finance literature in two divergent manners. The current study examines the investing behavior of short-term (transient) institutional investors in order to determine whether this investing behavior is more aptly characterized by the portrayal of transients as informed investors or whether the more malevolent portrayal of transients as short-termists who exploit information asymmetries more appropriately fits this investor class. The informed investor portrayal of transient investors describes their ability to acquire superior information and process that information to earn abnormal returns (Yan \& Zhang, 2009; Bin \& Ke, 2004). The short-termist portrayal is the more malevolent depiction of transient investors as opportunists who influence company management to focus on the near future at the expense of long-run value. This portrayal is supported by research which shows management is more likely to take value-destroying actions to meet short-term benchmarks when more transient investors are present (Bushee, 1998; Dikolli et al., 2009). In order to test the accuracy of the short-termist portrayal, the current study examines whether transient investors target and exploit poorly monitored firms. Transient investors may intentionally target poorly monitored firms in an effort to either 1) exploit an information asymmetry or 2) be able to more easily influence management to cater to their interests. While previous research has examined the actions taken by management in the presence of short-term investors, very few studies have examined whether transient investors intentionally target firms exhibiting a diminished quality of financial reporting. The current study fills this gap in the literature by examining whether transient owners directly target poorly monitored firms to earn abnormal returns.

To address the research question of whether transient institutional investors target and exploit poorly monitored firms, I utilize a model employed by Yan and Zhang (2009). This method employs a linear regression model to determine whether transient investors are attracted to firms with lower quality financial reporting as well as whether the higher returns earned by transient investors are more pronounced in firms with poor reporting quality. To measure the quality of financial reporting, I use three proxies for the degree of accounting discretion as identified by Bowen et. al. (2008), the amount of abnormal accruals, the degree of earnings smoothing, and the incidence of small positive earnings surprises. My results demonstrate that transient investors do not target firms with either larger abnormal accruals, higher amounts of earnings smoothing, or more small positive earnings surprises. In fact, transient owners appear to invest in firms that have a lower incidence of small earnings surprises. These results are inconsistent with the portrayal of transient investors as poor monitors who seek out firms with poor financial reporting. Instead, the results suggest transient owners may actually be attracted to firms with a higher quality of financial reporting. Furthermore, it is shown that transient investors do not earn greater returns in firms with more accounting discretion. 
Overall, there is no evidence to support the idea that transient owners earn superior returns by exploiting poorly monitored firms.

The current study examines the question of whether transient institutional investors truly are short-termists who exploit firms exhibiting greater accounting discretion. The results of this study do not support this malevolent portrayal. Instead, results support the portrayal of transient investors as informed investors who possess a superior ability to acquire and process information. This study contributes to the literature as it is one of the first studies to explore the degree to which transient institutions target firms which exercise greater accounting discretion. Furthermore, it is one of the first studies to examine the relation between the superior returns earned by transient institutions and the level of accounting discretion exhibited by the firms they hold shares in. While the results of this study do not necessarily contradict the findings of previous studies which show transient owners do not possess the same incentives to monitor as dedicated investors (see Liu \& Peng, 2008), the findings of this analysis are important as they show the depiction implicit in other studies that transient owners exploit the poor monitoring of the firms they invest in is not necessarily accurate. Due to the importance of the research question, further studies should continue to examine whether transient owners seek to exploit poor firm monitoring.

\section{Background}

\subsection{Shareholder Investment Horizon}

Shareholder investment horizon describes the length of time which a certain investor class normally holds a given investment before selling. Bushee (1998) classifies institutional investors into three different categories; transient, quasi-indexer, and dedicated investors. This classification is used to separate institutions into short-term versus long-term investors. To perform this classification, Bushee (1998) starts with a large number of variables utilized in the literature to describe trading behavior and portfolio characteristics. Principal factor analysis is then used to generate a small number of common factors that explain the overall variance of the factors. Finally, institutions are classified into groups using k-means cluster analysis in the factor scores. The result is a classification grouping institutions on 1) how well diversified their portfolio is and 2) how quickly they turn the portfolio over (shareholder investment horizon). (Note 1) Transient investors develop investment portfolios that are well-diversified and turn these portfolios over relatively fast. Quasi-indexing institutions hold portfolios that are relatively diverse but do not turn over their portfolios as fast as transient investors. Dedicated institutions hold concentrated portfolios and maintain a longer investment horizon relative to transient institutions. Accounting research has examined the implications to a firm of having shareholders fall into one of the three classes with the short-term or transient investor class representing the most scrutinized class of institutional investors. In the literature, transient investors are portrayed as being either informed investors who profit from superior information (Ke \& Petroni, 2004; Yan \& Zhang, 2009) or as short-termists and poor monitors of management whose actions cause management to focus solely on near-term results (Gaspar et al., 2005; Dikolli et al., 2009).

The informed investor portrayal of transient investors describes their ability to trade on private information obtained from management. Ke and Petroni (2004) show that transient investors can predict a break in hitting earnings benchmarks at least one quarter in advance of the event. In a follow-up study, they show this prediction ability of transient investors has diminished in the post-Reg FD environment (Ke et al., 2008), suggesting the superior predictive ability was accomplished via the acquisition of private disclosures from management. Yan and Zhang (2009) also portray transient investors as being relatively more informed and find that the ability of institutional investor trading to predict future returns (documented by Gompers \& Metrik, 2001) is completely driven by the trading behavior of transient institutions. Yan and Zhang (2009) attribute this superior ability to be the result of private disclosures obtained from management. Hu et al. (2009), show that transient institutions sell in the event of a small negative earnings surprise and this type of investor selling is informative as it is predictive of the following three month abnormal return on the security. These findings again reinforce the portrayal of transient institutions as informed investors, trading on superior information.

The second portrayal of transient investors in the literature is as shareholders solely focused on the short-term which leads company management to make suboptimal decisions in an attempt to cater to these investors. This is the more malevolent portrayal of transient investors. Bushee (1998) finds companies are more likely to cut research and development spending to meet earnings estimates when there are more transient shareholders present. Dikolli et al. (2009) find companies take into account the presence of transient shareholders when designing executive compensation packages. They show companies are less likely to give importance to meeting short-term earnings in compensation when there are more transient investors in the stock, indicating that companies understand the implicit pressure to focus on the short-term when transient investors are present. Finally, Gaspar et al. (2005) demonstrate target firms with short-term shareholders are more likely to receive an acquisition bid but get lower premiums and they attribute this finding to the poor monitoring of management by short-term shareholders. The authors hypothesize this poor monitoring allows managers to broker a deal for themselves that does not necessarily take into consideration the best interests of shareholders. The characterization of institutional investors as poor monitors does 
not apply to long-term institutions. Chen and Li (2007) show long-term institutions are more likely to engage in monitoring and financial gains arise from these monitoring activities.

While accounting literature has portrayed transient investors as poor monitors and short-termists, few studies have directly tested whether transient investors target firms with greater accounting discretion. Although accounting literature has identified numerous proxies for assessing the quality of financial reporting, few studies have tested whether transient owners truly target firms with a reduced quality of financial reporting. This test is important because it provides evidence regarding whether transient owners actually are short-termists who leverage information asymmetries present in poorly monitored firms.

\section{Hypothesis Development}

Transient investors have been shown to be informed investors who earn superior abnormal returns. These superior abnormal returns could result from superior trading ability and the unique ability to identify firm value. Alternatively, transient investors could merely target firms where there is an information asymmetry problem, thereby exploiting less informed investors. A high degree of accounting discretion is indicative of a firm where management is poorly monitored and an information asymmetry problem exists (Lin, 2006). If transient investors are short-termists who merely desire to maximize current returns, they will target poorly monitored firms, exploiting the information asymmetry between management and investors.

An alternative reason why transient investors may seek out firms with a higher degree of accounting discretion relates not to a pre-existing information asymmetry problem but to the perceived ability to influence management. Transient owners have been found to exert a short-term pressure on management (Bushee, 1998; Dikolli, 2009). To increase their ability to be successful in exerting this pressure, transient investors may target firms with a greater degree of accounting discretion due to the belief they can more easily influence firm management. A firm that is poorly monitored and already engaging in questionable financial reporting should be more likely to use mechanisms to manipulate financial reporting to appease the interests of short-term institutional investors. Thus, an alternative reason why transient investors may be attracted to firms with greater accounting discretion, in addition to the desire to exploit an information asymmetry problem, is the belief that these firms will be more likely to engage in questionable reporting practices and cater to their short-term interests. Collectively, these two explanations lead to my first hypothesis:

H1 - Transient Investors will be more likely to invest in firms with a higher degree of accounting discretion.

The second hypothesis addresses whether the higher returns associated with transient ownership are more prevalent in firms with greater accounting discretion. Transient owners have been shown to be informed (Yan and Zhang 2009; $\mathrm{Ke}$ and Petroni 2004). If returns are actually the result of collecting and processing information then there is no reason to believe transient investors will earn higher returns in firms with greater accounting discretion. As discussed previously, transient investors may follow a strategy of targeting firms with greater accounting discretion to 1) exploit an information asymmetry with lesser informed investors or 2) seek out firms where they believe company management may be more easily influenced. The goal of transient investors in engaging in these behaviors would be to earn positive abnormal returns. An important remaining question is whether the abnormal returns earned by transient investors are more heavily concentrated in firms with greater accounting discretion. If the returns of transient investors are earned through exploiting poorly monitored firms, it is likely these abnormal returns will be more heavily concentrated in firms with more accounting discretion, leading to my second hypothesis.

$\mathrm{H} 2$ - The association between transient ownership and positive future returns will be more pronounced in firms with greater accounting discretion.

\section{Methodology}

To test my hypothesis regarding whether transient investors are more likely to hold shares of firms with greater accounting discretion (H1) and whether superior returns earned by transient owners are more concentrated in firms with greater accounting discretion (H2), linear regressions are utilized similar to the method of Yan and Zhang (2009). The method employed in the current study differs from Yan and Zhang (2009) in using a panel dataset as opposed to annual cross-sectional regressions. This allows for easier interpretation of results. H1 states that transient investors will be more likely to hold shares in firms with a higher degree of accounting discretion. For the test of H1, an OLS regression is run where transient ownership is the dependent variable and the independent variables of interest are three proxies for accounting discretion. This tests whether the amount of accounting discretion in the firm explains transient-ownership and therefore whether transient owners are attracted to firms with a greater amount of accounting discretion. The regression is as follows:

TRA $=\alpha_{1}+\beta_{1} \mathrm{ABNACC}+\beta_{2} \mathrm{SMOOTH}+\beta_{3} \mathrm{SMP}+\beta_{4} \mathrm{MKTCAP}+\beta_{5} \mathrm{AGE}+\beta_{6} \mathrm{DP}+\beta_{7} \mathrm{BM}+\beta_{8} \mathrm{PRC}+\beta_{9} \mathrm{TURN}+$ $\beta_{10} \mathrm{VOL}+\beta_{11} \mathrm{SP} 500+\varepsilon$ 
The dependent variable is the percentage of transient investors (TRA). ABNACC is the average absolute value of quarterly abnormal accruals (see Dechow, Sloan, \& Sweeney, 1995) taken over the prior three year period. SMOOTH is a measure of earnings smoothing calculated as the standard deviation of operating cash flows divided by the standard deviation of earnings over the prior three years. SMP is a measure of the incidence of small positive earnings surprise and is calculated as the fraction of the prior 12 quarterly earnings surprises that were small positives. (Note 2) I expect the coefficients on all three accounting discretion variables to be positive, consistent with transient investors targeting firms with greater accounting discretion. MKTCAP is equal to the natural log of the firm's market capitalization with a coefficient expected to be positive because institutions exhibit a preference for larger firms. AGE is the number of months the firm has appeared in the CRSP database. The anticipated sign on this variable is negative as short-term investors have been shown to have a preference for younger firms (YZ, 2009). DP is equal to the company's dividend yield. The coefficient expected on DP is negative as short-term investors have been shown to prefer firms with lower dividend yields (YZ, 2009). BM is calculated as the firm's book-to-market value. (Note 3) It is expected that this coefficient is positive as institutions have been found to target firms with higher book values. PRC is the firm's share price. Due to the institutional preference for larger firms, it is expected that this coefficient will be positive. TURN is equal to the average monthly turnover over the previous quarter. The expected coefficient on TURN is positive as short-term institutions have been found to exhibit a strong preference for stocks with high turnover (YZ 2009). VOL is equal to the monthly volatility of the stock over the past two years. It is expected that the coefficient on VOL will be positive as it has been found that short-term investors invest in volatile stocks (YZ 2009). SP500 is an indicator variable equal to 1 if the firm was a member of the S\&P 500 Index. It is unclear what the direction of this coefficient will be as transient investors have not been shown to exhibit a preference for S\&P 500 stocks. Hypothesis H1 is supported by finding positive and significant coefficients on the three proxies for accounting discretion (ABNACC, SMOOTH, and SMP).

A specification of the same model using leading accounting discretion variables in place of current accounting discretion variables is also utilized in an attempt to differentiate between transient investors being attracted to firms with high current accounting discretion from transient investors being attracted to firms which will have higher future accounting discretion. Due to the superior information of transient investors, it is likely they could identify firms which may not be demonstrating high accounting discretion currently but may do so in the near future. This specification using future accounting discretion is as follows:

TRA $=\alpha_{1}+\beta_{1}$ LEADABNACC $+\beta_{2}$ LEADSMOOTH $+\beta_{3}$ LEADSMP $+\beta_{4}$ MKTCAP $+\beta_{5}$ AGE $+\beta_{6}$ DP $+\beta_{7}$ BM + $\beta_{8}$ PRC $+\beta_{9}$ TURN $+\beta_{10}$ VOL $+\beta_{11}$ SP500 $+\varepsilon$

The "lead" transformations of each accounting discretion variable (LEADABNACC, LEADSMOOTH, and LEADSMP) are equal to the value of the variable in year $t+1$. The predicted sign of the coefficients on all three of the current and leading accounting discretion variables is positive due to the hypothesis that transient investors will be attracted to firms with higher accounting discretion.

$\mathrm{H} 2$ states that the association between transient ownership and positive future returns will be more pronounced for firms with greater accounting discretion. To test $\mathrm{H} 2$, a regression similar to the test of $\mathrm{H} 1$ is run. In this regression, however, the three-month firm return is used as the dependent variable and transient ownership and the accounting discretion variables are included as independent variables. (Note 4) The independent variables of interest are the interactions between transient ownership and the accounting discretion variables. This will give an indication as to whether the positive future returns associated with transient ownership are more heavily concentrated in firms with greater accounting discretion. The regression is as follows:

RET3 $=\alpha_{1}+\beta_{1}$ TRA $+\beta_{2}$ ABNACC $+\beta_{3}$ SMOOTH $+\beta_{4}$ SMP $+\beta_{5}$ TRA*ABNACC $+\beta_{6}$ TRA $*$ SMOOTH + $\beta_{7} \mathrm{TRA} * \mathrm{SMP}+\beta_{8} \mathrm{MKTCAP}+\beta_{9} \mathrm{AGE}+\beta_{10} \mathrm{DP}+\beta_{11} \mathrm{BM}+\beta_{12} \mathrm{PRC}+\beta_{13} \mathrm{TURN}+\beta_{14} \mathrm{VOL}+\beta_{15} \mathrm{SP} 500+\varepsilon$

Again, a specification of the same model using leading accounting discretion variables in place of current accounting discretion variables is utilized in an attempt to differentiate between transient investors attracted to firms with high current accounting discretion from transient investors attracted to firms which will have higher accounting discretion in the near future. This specification using future accounting discretion is as follows:

RET3 $=\alpha_{1}+\beta_{1}$ TRA $+\beta_{2}$ LEADABNACC $+\beta_{3}$ LEADSMOOTH $+\beta_{4}$ LEADSMP $+\beta_{5}$ TRA $*$ LEADABNACC + $\beta_{6}$ TRA $*$ LEADSMOOTH $+\beta_{7}$ TRA $*$ LEADSMP $+\beta_{8}$ MKTCAP $+\beta_{9}$ AGE $+\beta_{10}$ DP $+\beta_{11}$ BM $+\beta_{12}$ PRC $+\beta_{13}$ TURN + $\beta_{14} \mathrm{VOL}+\beta_{15} \mathrm{SP} 500+\varepsilon$

RET3 is the future three-month cumulative return on the stock. The accounting discretion variables (ABNACC, SMOOTH, and SMP) are as defined previously with the exception that the variables in this specification are indicator variables equal to 1 if the firm accounting discretion variable is greater than the median. For example, if a company has ABNACC greater than the median firm for that year, ABNACC will be equal to 1 and will be 0 otherwise. All other variables are as defined previously. $\mathrm{H} 2$ is supported if the coefficient on any of the interaction variables is positive and significant, demonstrating transient owners earn greater returns in companies with higher accounting discretion. 


\section{Sample Selection}

The sample for my analyses contains data from CRSP, Compustat, Thompson-Reuters, and First Call databases. The time period covers the years 1998-2007. (Note 5) Bushee (1998) classifications are utilized to categorize institutional holdings data, as described previously. Institutional holdings data for the transient ownership variable (TRA) is gathered from the $13 \mathrm{f}$ filings on the Thomson-Reuters database.

\section{Results}

First, I present the results for the univariate tests in Table 1. Comparing the descriptive statistics of my dataset with those of Yan and Zhang (2009) yields interesting differences. The most striking contrast between my dataset and YZ (2009) is my average dividend yield (0.006) is far lower than that (0.021) reported by YZ (2009). The reason for this difference is the fact that Yan and Zhang (2009) only include dividend paying firms, as evidenced by a minimum amount on dividend yield greater than zero, while some firm observations have cash dividends equal to zero. (Note 6) Another difference between my dataset and that of Yan and Zhang (2009) is the average book-to-market ratio of my firms (0.623) is lower than that of Yan and Zhang (0.74). A final difference is the average turnover of the firms used in my sample (0.136) is higher than the level reported (0.078) in YZ (2009). Other than the differences described, the descriptive statistics of my dataset are consistent with those of Yan and Zhang (2009).

Table 1. Descriptive Statistics

\begin{tabular}{lcccccc}
\hline Variable & $\mathrm{N}$ & Mean & Median & Std. Dev. & $\mathrm{Q} 1$ & $\mathrm{Q} 3$ \\
\hline TRA & 24525 & 0.158 & 0.122 & 0.319 & 0.053 & 0.223 \\
ABNACC & 24525 & 0.713 & 0.197 & 2.130 & 0.068 & 0.499 \\
SMOOTH & 24525 & 2.849 & 1.833 & 4.955 & 0.966 & 3.274 \\
SMP & 24525 & 0.107 & 0.083 & 0.143 & 0.000 & 0.167 \\
MKTCAP & 24525 & 19.900 & 19.813 & 1.940 & 18.513 & 21.129 \\
COAGE & 24525 & 204.580 & 141.000 & 185.587 & 76.000 & 282.000 \\
DP & 24525 & 0.005 & 0.000 & 0.009 & 0.000 & 0.007 \\
BM & 24525 & 0.607 & 0.481 & 0.511 & 0.286 & 0.755 \\
PRC & 24525 & 23.260 & 16.938 & 33.565 & 7.500 & 31.210 \\
TURN & 24525 & 0.153 & 0.098 & 0.219 & 0.047 & 0.191 \\
RETVOL & 24525 & 0.148 & 0.125 & 0.094 & 0.087 & 0.183 \\
SP500 & 24525 & 0.126 & 0.000 & 0.332 & 0.000 & 0.000 \\
\hline
\end{tabular}

TRA - the percentage of the firm's stock owned by transient (see Bushee 1998) investors

ABNACC - abnormal accruals calculated using the modified Jones model over the prior three years

SMOOTH - earnings smoothing calculated as the std deviation of qtrly cash flows over std deviation of earnings

SMP - proportion of earnings surprises over the prior 12 quarters that were "small positive" earnings surprises

LEADABNACC, LEADSMP, and LEADSMOOTH - equal to ABNACC, SMP, and SMOOTH at year $\mathrm{t}+1$

MKTCAP - the natural log of the firm's market capitalization

COAGE - the number of months the firm has been listed in CRSP

DP - equal to firm dividend yield calculated as cash dividend divided by share price

$\mathrm{BM}$ - the firm's book-to-market ratio calculated as common equity divided by market capitalization

PRC - equal to the price of the firm's stock

TURN - equal to the average of the previous three months turnover for the firm's stock

RETVOL - the volatility of firm stock taken as the std deviation of returns over the previous 24 months

SP500 - indicator variable equal to 1 if the firm was listed in the SP500 for the year

Next, the three proxies for accounting discretion (ABNACC, SMOOTH, and SMP) are analyzed by transient ownership quintile in each year. TRA_Q1 represents the quintile with the greatest amount of transient ownership while TRA_Q5 represents the quintile with the least. The results are presented graphically in Figure 1. With respect to abnormal accruals (ABNACC), it appears that firms with less transient owners appear to have a greater amount of abnormal accruals. Specifically, in seven of the ten years analyzed, ABNACC is highest in the quintile with the smallest amount of transient ownership (TRA_Q5). The results for earnings smoothing (SMOOTH) are also inconsistent with transient ownership being associated with more accounting discretion. In the first seven years of the sample, greater earnings smoothing is concentrated in firms which have an average amount of transient investors. However, in the last three years of the sample, greater earnings smoothing appears to be concentrated in the quintiles with the lowest amount of transient ownership. With respect to small positive earnings surprises, the results overwhelmingly indicate that the firms with the least amount of transient ownership have the greatest amount of 
small positive earnings surprises (SMP). In seven of the ten years of the sample, the two quintiles with the greatest amount of small positive earnings surprises are Q3, Q4, or Q5. Overall, the univariate results are inconsistent with transient owners being associated with greater accounting discretion.
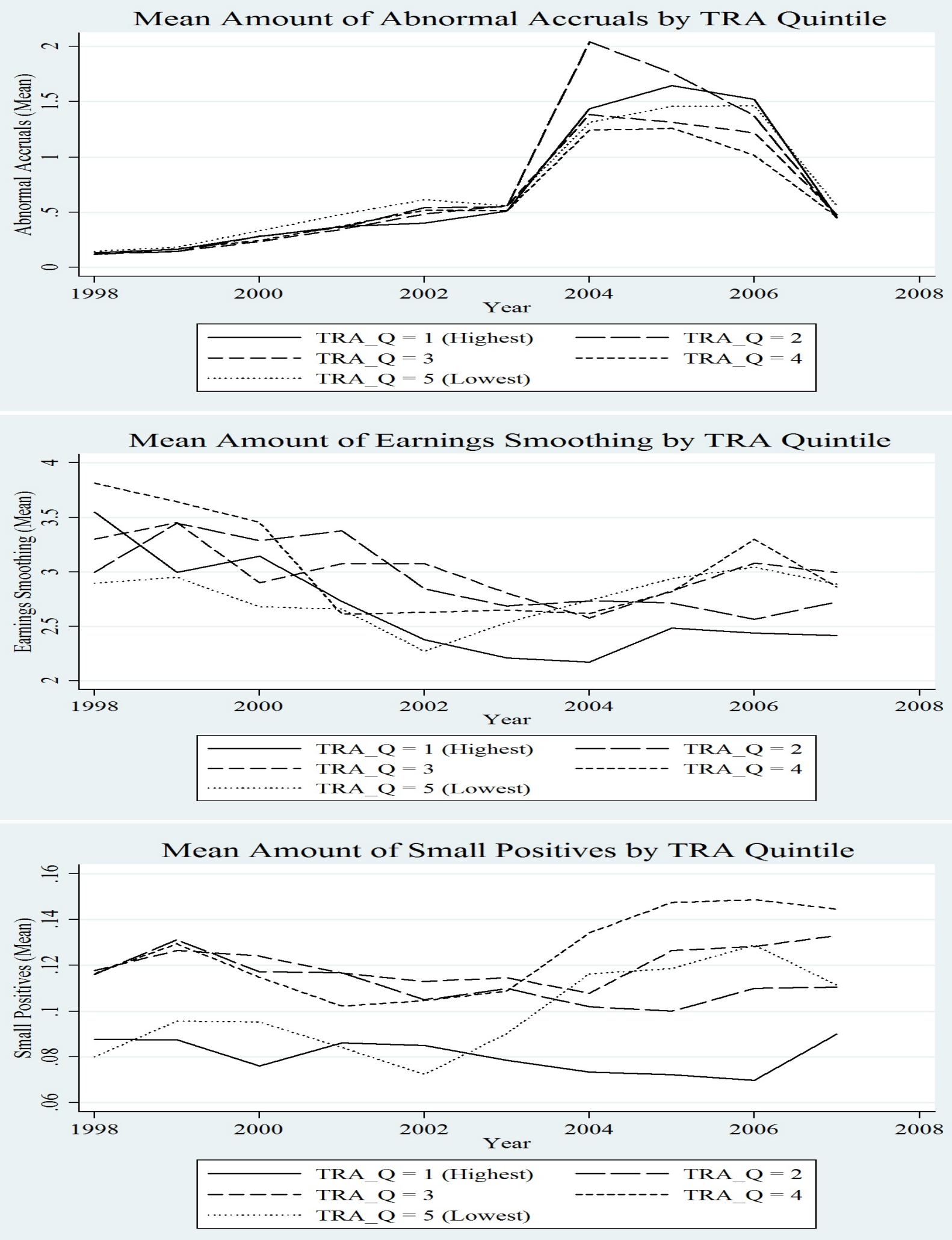

Figure 1. Accounting Discretion in Transient-Owned Firms 
Next, the results for the regression utilizing accounting discretion variables are presented in Table 2. As discussed previously, a linear regression is run over the ten-year sample period. Results for the control variables are generally consistent with YZ (2009). The findings are presented in Table 2. These results indicate transient owners prefer firms that are larger, younger and have lower dividend yields and higher turnover. Inconsistent with the findings of $\mathrm{YZ}$ (2009), transient ownership is not found to be significantly associated with the firm's book-to-market ratio.

For my first test of H1, employing current accounting discretion variables (Eq. 1a), I fail to find evidence consistent with the hypothesis that transient investors are attracted to firms with greater accounting discretion. In fact, results indicate an opposite effect. The coefficient on ABNACC is negative and significant (coeff. $=-0.00396$; $p$-value $<.0001$ ). Furthermore, a strong negative association is found between transient ownership and the incidence of small positive earnings surprises. The coefficient on SMP is negative and significant (coeff. $=-0.04233$; $\mathrm{p}$-value $<.0001$ ). Regarding earnings smoothing, there is marginal evidence that transient investors target firms with greater earnings smoothing. The coefficient on SMOOTH is positive (coeff. $=0.00033$ ) and significant at the five percent level ( $p$-value $=0.046)$. In summary, the results are inconsistent with the hypothesis that transient investors are targeting firms exercising greater amounts of accounting discretion.

Results are similar when leading accounting discretion variables replace current discretion variables (Eq. 1b). Transient ownership is negatively associated with lead abnormal accruals (coeff. $=-0.00320$ ) and the coefficient is highly significant $(\mathrm{p}$-value $<.0001)$. Similar to the specification using current accounting discretion variables, a strong negative association between small positive earnings surprises and transient ownership is exhibited. The coefficient on LEADSMP is -0.03651 and is highly significant ( $\mathrm{p}$-value $=0.001$ ). Finally, the coefficient on LEADSMOOTH is positive and significant at the five percent level ( $p$-value $=0.041$ ). This again is consistent with transient owners targeting firms with greater earnings smoothing but overall, tests fail to document a positive association between transient ownership and greater accounting discretion.

To control for the potential effects of multicollinearity among the accounting discretion variables, separate regressions were run using only one accounting discretion variable at a time. These results are omitted for the sake of brevity but are fully consistent with the results obtained using all three accounting discretion variables simultaneously.

Table 2. Association Between Transient Ownership and Accounting Discretion

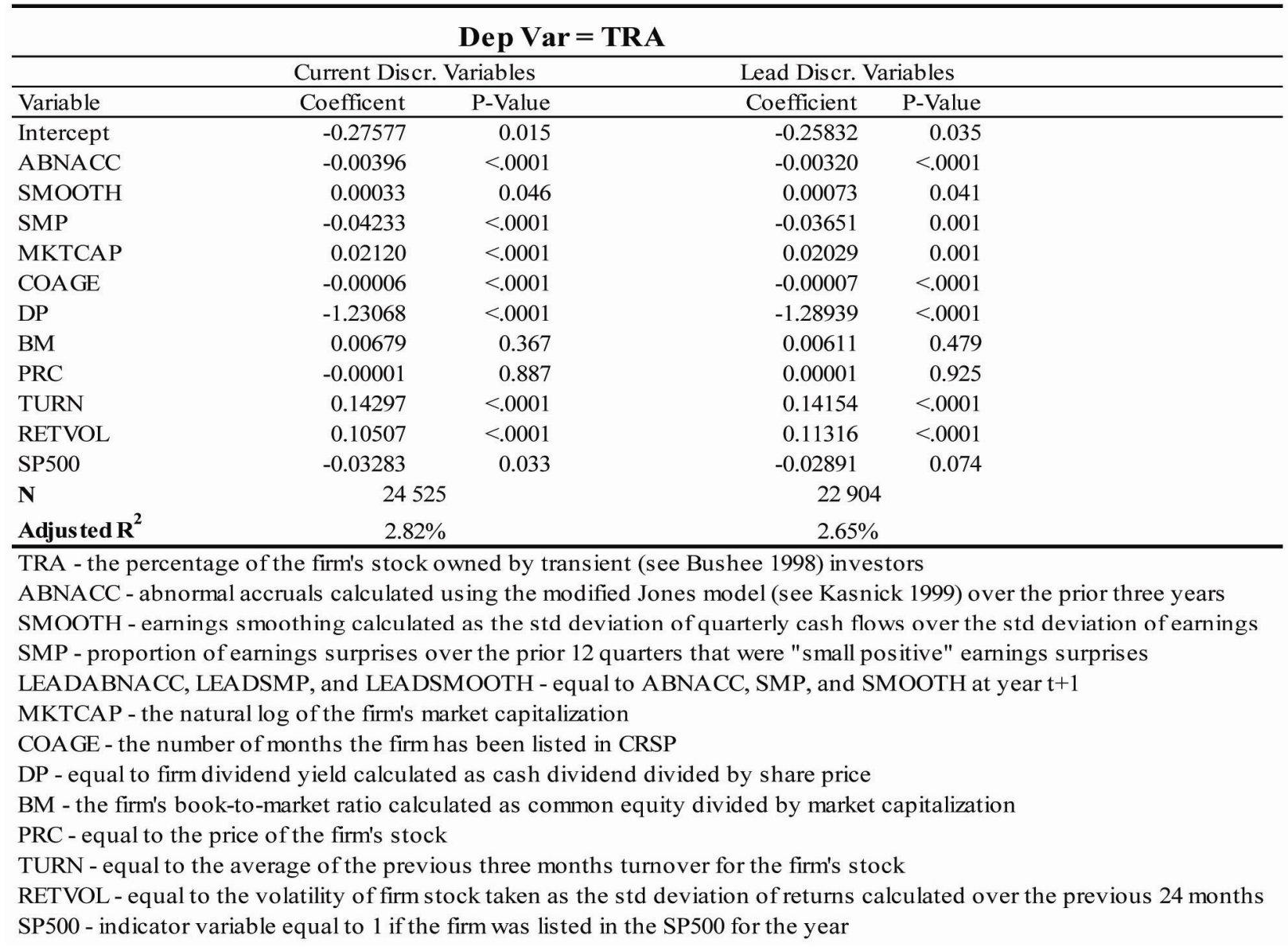


Next in Table 3, results are presented for the test of $\mathrm{H} 2$ which states the association between firm returns and transient ownership will be more pronounced for firms with greater accounting discretion (Eq. 2a). This test regresses the three-month return (RET3) of the stock on transient ownership, the three accounting discretion variables, and a series of control variables. In this regression, the coefficient on TRA is positive and highly significant (coeff. $=0.1756$; $\mathrm{p}$-value $<.0001$ ). This is consistent with prior literature which demonstrates that transient investors generate positive abnormal short-term returns. Next, the coefficients on the accounting discretion variables are analyzed. The coefficient on ABNACC is positive and significant (coeff. $=0.01262 ; \mathrm{p}$-value $=0.026$ ). This is consistent with literature showing that firms which engage in short-term earnings management experience higher returns as a result of this behavior. SMOOTH is also positive and significant (coeff. $=0.02241 ; \mathrm{p}$-value $<.0001$ ). The coefficient on SMP is not found to be significantly related to short-term returns.

Table 3. Association between Firm Returns and Accounting Discretion

\begin{tabular}{|c|c|c|c|c|}
\hline \multicolumn{5}{|c|}{ Dep Var $=$ RET 3} \\
\hline & \multicolumn{2}{|c|}{ Current Discr. Variables } & \multicolumn{2}{|c|}{ Lead Discr. Variables } \\
\hline Variable & Coefficent & P-Value & Coefficient & P-Value \\
\hline Intercept & -0.01201 & 0.719 & -0.02830 & 0.398 \\
\hline TRA & 0.17566 & $<.0001$ & 0.14764 & $<.0001$ \\
\hline ABNACC & 0.01262 & 0.026 & 0.02553 & $<.0001$ \\
\hline SMOOTH & 0.02241 & $<.0001$ & 0.03022 & $<.0001$ \\
\hline SMP & -0.00203 & 0.759 & 0.00267 & 0.655 \\
\hline TRA*ABNACC & -0.06583 & 0.007 & -0.06933 & 0.002 \\
\hline TRA *SMOOTH & -0.10853 & $<.0001$ & -0.03013 & 0.261 \\
\hline TRA*SMP & -0.04581 & 0.148 & -0.04894 & 0.053 \\
\hline MKTCAP & 0.00012 & 0.943 & 0.00025 & 0.878 \\
\hline COAGE & -0.00002 & 0.046 & -0.00003 & 0.019 \\
\hline DP & 0.15478 & 0.494 & 0.16453 & 0.466 \\
\hline $\mathrm{BM}$ & 0.03132 & $<.0001$ & 0.03337 & $<.0001$ \\
\hline PRC & -0.00006 & 0.356 & -0.00008 & 0.235 \\
\hline TURN & -0.03642 & $<.0001$ & -0.03514 & $<.0001$ \\
\hline RETVOL & 0.26535 & $<.0001$ & 0.27739 & $<.0001$ \\
\hline SP500 & 0.03081 & $<.0001$ & 0.03143 & $<.0001$ \\
\hline LAGRET3 & -0.08100 & $<.0001$ & -0.08234 & $<.0001$ \\
\hline LA GRET12 & -0.00957 & $<.0001$ & -0.00990 & $<.0001$ \\
\hline $\mathbf{N}$ & \multicolumn{2}{|c|}{24485} & \multicolumn{2}{|c|}{24485} \\
\hline Adjusted $\mathbf{R}^{2}$ & \multicolumn{2}{|c|}{$2.08 \%$} & \multicolumn{2}{|c|}{$2.24 \%$} \\
\hline
\end{tabular}

RET3 - the three month cumulative return on the stock

TRA - the percentage of the firm's stock owned by transient (see Bushee 1998) investors

ABNACC - abnormal accruals calculated using the modified Jones model (see Kasnick 1999) over the prior three years

SMOOTH - earnings smoothing calculated as the std deviation of quarterly cash flows over the std deviation of earnings

SMP - proportion of earnings surprises over the prior 12 quarters that were "small positive" earnings surprises

LEADABNACC, LEADSMP, and LEADSMOOTH - equal to ABNACC, SMP, and SMOOTH at year $\mathrm{t}+1$

MKTCAP - the natural log of the firm's market capitalization

COAGE - the number of months the firm has been listed in CRSP

DP - equal to firm dividend yield calculated as cash dividend divided by share price

$\mathrm{BM}$ - the firm's book-to-market ratio calculated as common equity divided by market capitalization

PRC - equal to the price of the firm's stock

TURN - equal to the average of the previous three months turnover for the firm's stock

RETVOL - equal to the volatility of firm stock taken as the std deviation of returns over the previous 24 months

SP500 - an indicator variable equal to 1 if the firm was listed in the SP500 for the year

LAGRET3 - the lagged three month cumulative return on the stock

LAGRET12 - the lagged twelve month cumulative return on the stock 
Next, the interactions between transient ownership and the accounting discretion variables are discussed. The results do not support the hypothesis that transient owners earn greater returns in firms with higher accounting discretion, exhibited by a lack of positive and significant coefficients on the three interaction variables. The interaction variable TRA*ABNACC is negative and significant (coeff. $=-0.06583 ; \mathrm{p}$-value $=0.007$ ). The interaction variable TRA*SMOOTH is also negative and significant (coeff. $=-0.10853$; $p$-value $<.0001$ ). The interaction variable TRA*SMP, however, is insignificant. Overall, the results suggest there is not a relation between the magnitude of the returns earned by transient investors and the amount of accounting discretion demonstrated in the firm. In fact, results depict transient investors as earning smaller returns in firms which exhibit greater accounting discretion, inconsistent with the belief that transient investors generate returns by exploiting poorly monitored firms. (Note 7)

Next, the same test is run with the exception that lead accounting discretion variables are used in place of current accounting discretion variables (Eq. 2b). When lead accounting discretion variables are used as the independent variables of interest, transient ownership remains significantly related to future returns. Furthermore, the results on the accounting discretion variables continue to show a positive and significant relation between returns and accounting discretion. The coefficient on ABNACC is positive and significant and the coefficient on SMOOTH is also positive and significant. The coefficient on SMP is insignificant. Concerning the interaction variables, TRA*ABNACC is negative and significant while the coefficient on TRA*SMOOTH is insignificant. Finally, the coefficient on TRA*SMP is found to be negative and is significant at the ten percent level. Overall, the results show that the superior returns of transient investors are not concentrated in firms with greater accounting discretion. Again, the findings do not support the hypothesis that transient owners intentionally target poorly monitored firms.

Separate regressions were again run using only one accounting discretion variable at a time to control for the potential effects of multicollinearity. The unreported results are consistent with the results obtained using all three accounting discretion variables simultaneously. This demonstrates that the superior returns earned by transient owners are not earned by targeting firms with greater accounting discretion. (Note 8)

\section{Discussion and Conclusion}

This study attempts to present evidence to either substantiate or undermine the portrayal of transient investors as short-termists who target and exploit poorly monitored firms. The study tests both the degree to which transient investors are attracted to poorly monitored firms and the propensity with which transient investors earn abnormal returns by trading in firms with greater accounting discretion. The results of the study are inconsistent with the short-termist portrayal of transient investors. Transient investors are not found to be attracted to firms with larger abnormal accruals, higher earnings smoothing, or increased incidences of small positive earnings surprises. In fact, transient institutions tend to target firms with a reduced amount of small positive earnings surprises. These results are inconsistent with the hypothesis that transient investors target poorly monitored firms or those where they can more easily influence management.

With respect to the abnormal returns earned by transient owners, no association is found between these returns and greater accounting discretion. In other words, the relatively superior returns earned by transient investors are not more heavily concentrated in companies which exercise greater accounting discretion.

Overall, the results of my study are inconsistent with the portrayal of transient investors as short-termists who seek out firms where they can influence company management and exploit information asymmetries. Further research should examine this important question of whether short-term institutional investors specifically target firms with greater accounting discretion by using different proxies for financial reporting quality. Additionally, research should attempt to identify mechanisms through which short-termist behavior could operate and not be associated with increased accounting discretion in firm financial reporting. Due to the importance of this research question, this study should not be considered a definitive answer to the question of whether the short-term interests of transient investors lead them to target firms exhibiting a monitoring deficiency. However, the current study does make an important contribution to the transient investor debate by presenting results which call into question the oftentimes implicit portrayal of transient owners as short-termists who earn superior returns merely by targeting firms where they can exploit information asymmetries.

\section{Acknowledgement}

I would like to acknowledge Kerry Inger, Ryan D. Leece, and John J. Maher for their helpful comments and suggestions. 


\section{References}

Bowen, R.M., Rajgopal, S., \& Vetkatachalam, M. (2008). Accounting Discretion, Corporate Governance, and Firm Performance. Contemporary Accounting Research, 25(2), 351-405. http://dx.doi.org/10.1506/car.25.2.3

Bushee, B., (1998). The influence of institutional investors on myopic R\&D investment behavior. Accounting Review, 73, 305-333.

Chen, X., Harford, J., \& Li, K., (2007). Monitoring: which institutions matter? Journal of Financial Economics, 86, 279-305. http://dx.doi.org/10.1016/j.jfineco.2006.09.005

Dechow, P.M., Sloan, R.G., \& Sweeney, A.P., (1995). Detecting Earnings Management. The Accounting Review, 70(2), 193-225.

Dikolli, S.S, Kulp, S.L., \& Sedatole, K.L., (2009). Transient institutional ownership and CEO contracting. The Accounting Review, 84, 737-770. http://dx.doi.org/10.2308/accr.2009.84.3.737

Gaspar, J.M., Massa, M., \& Matos, P, (2005). Shareholder investment horizons and the market for corporate control. Journal of Financial Economics, 76, 135-165. http://dx.doi.org/10.1016/j.jfineco.2004.10.002

Gompers, P., Ishii, J., \& Metrick, A., (2001). Institutional Investors and Equity prices. Quarterly Journal of Economics, 116(1), 229-259. http://dx.doi.org/10.1162/003355301556392

Hu, G., Ke, B., \& Yu, Y., (2009). Do Transient Institutions Overreact to Small Negative Earnings Surprises? Babson College, Pennsylvania State, and University of Texas Working Paper Series, 1-59. http://dx.doi.org/10.2139/ssrn.1495384

Ke, B., \& Petroni, K., (2004). How Informed Are Actively Trading Institutional Investors? Evidence from Their Trading Behavior Before a Break in a String of Consecutive Earnings Increases. Journal of Accounting Research, 42, 895-927. http://dx.doi.org/10.1111/j.1475-679X.2004.00160.x

Ke, B., Petroni, K., \& Yu, Y., (2008). The Effect of Regulation FD on Transient Institutions' Trading Behavior. Journal of Accounting Research, 46(4), 853-883. http://dx.doi.org/10.1111/j.1475-679X.2008.00296.x

Liu, L., \& Peng, E., (2008). Institutional Ownership Composition and Accruals Quality. California State - Fullerton and Fordham University Working Paper Series, 1-39. http://dx.doi.org/10.2139/ssrn.929582

Lin, H., (2006). Accounting Discretion and Managerial Conservatism: An Inter-temporal Analysis. Contemporary Accounting Research, 23(4), 1017-1041. http://dx.doi.org/10.1506/0343-6720-V320-4730

Yan, X. \& Zhang, Z., (2009). Institutional investors and equity returns: are short-term institutions better informed. The Review of Financial Studies, 22(2), 893-924. http://dx.doi.org/10.1093/revfin/hhl046

\section{Notes}

Note 1. I would like to acknowledge Brian Bushee for making his institutional investor classifications available for research purposes.

Note 2. A small positive surprise occurs when the change in seasonally lagged quarterly earnings after $\operatorname{tax}\left(\mathrm{E}_{\mathrm{q}}-\mathrm{E}_{\mathrm{q}-4}\right)$ scaled by total assets at the end of quarter q- 5 falls within the range of $(0.00$ to 0.0025$)$.

Note 3. Following YZ (2009), firm book-to-market and dividend yield are winsorized at the $1^{\text {rst }}$ and $99^{\text {th }}$ percentile.

Note 4. This model using returns regressed on transient ownership is also adopted from Yan and Zhang (2009).

Note 5. Only firm observations with three consecutive years of data were included in my sample. This restriction reduced my sample size from 27,188 observations to 24,525 observations.

Note 6. Missing cash dividend amounts were set to zero.

Note 7. Following Yan and Zhang (2009), I also performed tests using twelve month returns as the dependent variable. The results did not conflict with the main tenor of my results but due to the insignificance of the coefficients on the control variables and the variables of interest, the test results were omitted.

Note 8. The model was also run using annual cross-sectional regressions (see Yan and Zhang 2009). Results were similar to those obtained using a panel data specification. 